\title{
РЕКЛАМНИЙ ТЕКСТ ЯК ФУНКЦІОНАЛЬНИЙ РІЗНОВИД МОВЛЕННЯ
}

Арешенкова О. Ю. Рекламний текст як функціональний різновид мовлення.

У статті зроблено огляд різних трактувань реклами як форми діяльності та запропоновано узагальнену класифікацію рекламних повідомлень. Схарактеризовано рекламне мовлення як вид масової комунікації, описано модель рекламної комунікації. Подано комунікативно-мовленнєві характеристики рекламного тексту та зроблено спробу визначити місце текстів реклами в системі функціональних стилів.

Ключові слова: реклама, масова комунікація, рекламна комунікація, комунікативний акт, рекламний текст, інформаційний стиль, рекламний підстиль.

Арешенкова А. Ю. Рекламный текст как функциональная разновидность речи.

В статье сделан обзор разных трактовок рекламы как формы деятельности и предложена обобщенная классификация рекламных сообщений. Охарактеризовано рекламное вещание как вид массовой коммуникации, описана модель рекламной коммуникации. Поданы коммуникативно-речевые характеристики рекламного текста и сделана попытка определить место текстов рекламы в системе функциональных стилей.

Ключевые слова: реклама, массовая коммуникация, рекламная коммуникация, коммуникативный акт, рекламный текст, информационный стиль, рекламный подстиль.

Areshenkova O. Yu. Advertisement text as functional variety of speech.

In the article the review of different interpretations of advertisement as forms of activity is done and the generalized classification of advertisement reports offers. Advertisement speech as type of mass communication and the model of advertisement communication is described. Communicative-speech descriptions of advertisement text are given and to define the place of texts of advertisement in the system of functional styles was given it a shoot.

Key words: advertisement, mass communication, advertisement communication, communicative act, advertisement text, informative style, advertisement substyle.

Сьогодні реклама стала невід’ємною частиною сучасного життя і перетворилася на один з основних елементів інфраструктури засобів масової інформації. Головне призначення реклами - сприяти продажу товарів, спонукати споживачів до бажаної дії через рекламне повідомлення, що поєднує в собі як інформацію, так і переконання. Вплив на адресата є базовою функцією реклами, тому засоби ії реалізації являють собою один із найважливіших компонентів мовної структури. 
Посилення ролі реклами в сучасному світі зумовило активізацію інтересу до вивчення цього суспільного феномена серед науковців різних галузей: психології, соціології, політології, журналістики. Учені-лінгвісти передусім звернули увагу на мовностилістичні особливості реклами, згодом постали проблеми, пов'язані 3 комунікативно-прагматичними параметрами рекламного тексту, 3-поміж яких питання вербального впливу на адресата залишається малодослідженим в українському мовознавстві.

Реклама визначається «Словником іншомовних слів», «Словником української мови» та «Словником рекламних термінів» як популяризація товарів чи послуг задля привернення уваги споживачів за допомогою преси, радіо, телебачення тощо [30, с. 579; 31, т. VIII, с. 493; 10, с. 144].

Т. Примак називає рекламу платною неперсоніфікованою формою інформаційного впливу на споживача, метою якого $\epsilon$ формування мотивів купівлі товарів [24, с. 13]; С. Тюріна - потужною галуззю індустрії й продуктом іiі діяльності, який спрямований на забезпечення потенційного адресата рекламного повідомлення інформацією про товари / послуги задля їх популяризації [34, с. 1]; Б. Обритько стверджує, що реклама - це друковане, рукописне, усне або графічне повідомлення про особу, товари, послуги або суспільний рух, відкрито опубліковане рекламодавцем й оплачене, що має на меті збільшення обсягів збуту, розширення клієнтури, одержання голосів або суспільної підтримки [21, с. 5].

Д. Розенталь у книзі «Мова рекламних текстів» характеризує рекламу як ознайомлення споживачів 3 товарами / послугами, які пропонує виробниче, торгівельне, транспортне, страхове, фінансовокредитне або інше підприємство [27, с. 4]; М. Кохтєв у роботі «Реклама: мистецтво слова» визначає рекламу як інформування людей різними способами аби створити широку популярність чому- або кому-небудь [14, с. 3]. Близьким до цього є визначення Ф. Джефкінса, у якому уточнюється, що реклама - це найпереконливіший спосіб інформування потенційних споживачів про певний товари / послуги [8, с. 10].

Досить специфічним, на наш погляд, є визначення у статті «Вибух комунікації. Народження нової ідеології» Ф. Бретона та С. Пру. Автори розкривають поняття реклами як необхідної покупцеві інформації для продуманого вибору, що сприяє естетизації повсякденного життя та численних предметів ужитку; забезпечує 
споживачеві абсолютну свободу та незалежність у прийнятті ним рішень [25, с. 56]. У свою чергу, укладачі своєрідної енциклопедії рекламної діяльності «Реклама: теорія та практика» Ч. Сендидж, В. Фрайбургер та К. Ротцолл звертають увагу на рекламу як форму комунікації, що прагне перекласти якості товарів, послуг, а також ідеї на мову потреб і запитів споживача [33, с. 54] та ін.

Якщо спробувати узагальнити всі подані визначення, то рекламу можемо характеризувати як найпереконливіший спосіб інформування споживачів про товари / послуги.

Оскільки реклама складне та унікальне явище, вона має різні потрактування та зазнає неоднозначної типологічної диференціації. Проаналізована література дає змогу виділити узагальнену класифікацію реклами: за видом (комерційна, соціальна, політична); за способом передачі рекламної інформації (реклама у 3МI, пряма реклама, особиста реклама); за характером емоційного впливу (раціональна, емоційна); за метою повідомлення (інформативна, переконувальна, нагадувальна); за формою (медійна, зовнішня, друкована); за охопленням споживацької аудиторії (міжнародна, національна, регіональна, місцева) [27 с. 17; 21, с. 9-16; 6, с. 478-480; 3 , c. 20-26; 10, c. 203-205].

Функціональна значущість мовних засобів впливу в рекламних текстах зумовлена комунікативною та апелятивною функціями мови, які є базовими для рекламного тексту. Іншими словами, через мовний вплив рекламного повідомлення відбувається комунікація між копірайтером та адресатом. Відтак рекламне повідомлення специфічна форма комунікації.

Власне комунікацію визначають як спілкування, передача інформації, обмін інформацією $[28$, с. $243 ; 1$, с. $163 ; 29$, с. $13 ; 9$, с. 79 ; 11, с. 10]. Масове поширення інформативних повідомлень реклами дає підстави віднести іiї до однієї з форм масової комунікації (Ф. Бацевич, С. Бибик, І. Білодід, А. Загнітко, С. Квіт, М. Кохтєв, О. Назайкін, Б. Обритько, В. Різун, Д. Розенталь, С. Тюріна та ін.). Тому серед масової комунікації самостійно виділяється рекламна комунікація сучасний рекламний механізм, один з різновидів масової комунікації зі специфічними критеріями та параметрами якості [10, с. 77].

Основою рекламної комунікації $\epsilon$ адресант (особа / фірма / агенція, що забезпечує рекламну комунікацію, відправник рекламного повідомлення) та адресат (споживач, що сприймає інформацію). Поділяють процес рекламної комунікації на 
такі фази: кодування (розробка концепції реклами) $\rightarrow$ сприйняття $\rightarrow$ передача рекламного звернення $\rightarrow$ взаємодія [21, с. 63]. Партнери характеризуються множинністю, роз'єднаністю у просторі та часі. Рекламне звернення адресується аудиторії, яка $\epsilon$ неоднорідною за складом, різною за поінформованістю, за соціально-економічними параметрами і т. ін. [10, с. 77].

Незважаючи на те, що специфічною особливістю рекламного мовлення є відсутність безпосереднього контакту між комунікатором та реципієнтом, неможливість адресата миттєво відреагувати на репліку / зауваження автору повідомлення, комунікація все ж відбувається за моделлю: автор реклами кодує інформацію (розробляє концепцію реклами) $\rightarrow$ копірайтер створює рекламний текст $\rightarrow$ адресант ініціює відправлення повідомлення до дистанційного адресата $\rightarrow$ споживач зазнає певного впливу з боку реклами та $\rightarrow$ реагує на прагматичну настанову реклами.

Якщо реклама визначена як специфічна форма комунікативного акту, виникає питання й про місце рекламних текстів у системі функціональних стилів.

У сучасній лінгвістиці питання про стильовий статус реклами залишається дискусійним. Більшість мовознавців відносять рекламні тексти до публіцистичного стилю (І. Анніна, І. Кочан, М. Кохтєв, Д. Розенталь та ін.). Такий погляд видається нам досить суперечливим: рекламні тексти змістовно відрізняються від публіцистичних темою та функцією: у публіцистиці розглядаються суспільно важливі подіі, у рекламі - товар/послуга. Основною функцією рекламних текстів є не стільки інформування потенційного споживача, скільки вплив на нього [32, с. 636].

Актуалізація апелятивної функції мови в рекламних текстах, а саме: привернення уваги адресата до повідомлення, вплив на споживачів, аргументація необхідності придбати товар та інформативної функції (надання нової інформації про товар чи послугу) не дозволяє дати чітку категоризацію текстам реклами. Проте деякі мовознавці розглядають рекламні тексти в так званому стилі інформації, зокрема С. Бибик, І. Білодід, О. Зелінська, Т. Ковалевська, О. Пономарів, Г. Почепцов, І. Стернін та ін.

Залишається не вирішеним питання і про статус рекламних текстів як різновиду інформаційного стилю. 3 огляду на те, що в мовознавстві виділяють власне інформаційний та коментарний підстилі, тексти реклами доречно виокремлювати в рекламний 
підстиль, формою існування якого $є$ комерційні оголошення інформативного, переконливого та нагадувального характеру.

Попри значну кількість мовознавчих досліджень 3 рекламознавства, визначення поняття «рекламний текст» широко не розкрито в сучасній лінгвістиці. Так, фахівці рекламної діяльності характеризують такий текст як всі слова в друкованій або телевізійній рекламі [7, с. 346]; для мовознавства - це завершене повідомлення, що характеризується чітко орієнтованою прагматичною спрямованістю.

Нам видається близькою позиція С. Бибик, яка кваліфікує рекламний текст як закінчене висловлення 3 визначеною формальною i змістовою структурою, що виконує роль комунікативного повідомлення 3 інформацією про предмет реклами, 3 позитивною прагматичною настановою спонукати адресата до активної дії придбати цей товар [4, с. 326].

Складні комунікативні обставини спричиняють особливі вимоги до рекламних текстів. Для того аби створювати ефективні тексти реклами, копірайтери користуються певним правилом, а саме: максимум інформації при мінімумі слів. Водночас рекламний текст має бути конкретним i цілеспрямованим, доказовим, логічно побудованим, коротким та лаконічним. Крім того, він має бути цікавим, оригінальним та неповторним у деталях. Основна думка може бути виражена у формі рекламного лозунгу/слогану. Як правило, у текстах реклами акцентуються ті особливості, які відрізняють рекламований об'єкт від інших [27, с. 28-39].

Для реалізації комунікативно-прагматичної настанови рекламних повідомлень копірайтери вдаються до різноманітних мовних засобів їх увиразнення. В арсеналі творців рекламних текстів найчастіше вживаються прикметники, що безпосередньо вказують на ознаку рекламованого предмета, його властивість та характеристику. Нерідко звертаються й до зображальних засобів, щоб привернути увагу адресата на зміст та форму тексту: частіше використовують епітети та метафори; рідше - гіперболи та стилістичні фігури.

Окремим видом масової комунікації є рекламна комунікація, специфічною особливістю якої $\epsilon$ спрямування повідомлення дистанційному адресату. Тексти реклами не лише інформують споживача про товар / послугу, але й впливають на нього.

Основною формою існування рекламних текстів є комерційні оголошення інформативного, переконливого та нагадувального характеру. За комунікативно-прагматичними параметрами та 
мовностилістичними характеристиками цей тип текстів можна віднести до інформаційного стилю, надавши ї статус окремого, рекламного підстилю.

\section{Література}

1. Арешенков Ю. О. Лінгвістичний аналіз художнього тексту : [навчальний посібник для студентів навч. закладів] / Юрій Олександрович Арешенков. - Кривий Ріг : Видавничий дім, 2007. - 178 с.

2. Бацевич Ф.С. Основи комунікативної лінгвістики : [підручник] / Флорій Сергійович Бацевич. - К. : ВЦ «Академія», 2004. - 344 с.

3. Беклешов Д. В. Реклама: её функции, цели и методы создания / Д. В. Беклешов, В. П. Самусев. - К. : Издательство «Реклама», 1974. - 195 с.

4. Бибик С. П. Усна літературна мова в українській культурі повсякдення / Світлана Павлівна Бибик - Ніжин : Аспект-Поліграф, 2013. - 589 с.

5. Ганич Д. І. Словник лінгвістичних термінів / Д. І. Ганич, І. С. Олійник. - К. : Вища школа, 1985. - 360 с.

6. Гриценко Т. Б. Українська мова та культура мовлення : [навчальний посібник] / Тетяна Борисівна Гриценко. - К. : Центр навчальної літератури, 2003. - 536 с.

7. Денисон Д. Учебник по рекламе. Как стать известным, не тратя денег на рекламу / Д. Денисон, Л. Тоби. - Мн. : Современное слово, 1997. - 320 с.

8. Джефкінс Ф. Реклама : [практичний посібник] / Френк Джефкінс. - [4-е вид.]. К. : Знання, 2001. -456 с.

9. Єрмоленко С. Я. Українська мова : Короткий тлумачний словник лінгвістичних термінів / С. Я. Єрмоленко, С. П. Бибик, О. Г. Тодор; за ред. С. Я. Срмоленко. - К. : Либідь, 2001. - 224 с.

10. Іванченко Р. Г. Реклама : словник термінів / Р. Г. Іванченко. - К., 1998. - 207 с.

11. Квіт С. Масові комунікації : [підручник] / Сергій Квіт. - К. : Видавничий дім «Києво-Могилянська академія», 2008. - 206 с.

12. Коваль А. П. Практична стилістика сучасної української мови : [підручник] / Алла Петрівна Коваль. - К. : Вища школа, 1987. - 350 с.

13. Косенко Ю. В. Основи теорії мовної комунікації : [навчальний посібник] / Ю. В. Косенко. - Суми : Сумський державний університет, 2001. - 187 с.

14. Кохтев Н. Н. Реклама : искусство слова. [рекомендации для составителей рекламных текстов] / Николай Николаевич Кохтев. - М. : Издательство МГУ, 1997. - 96 с.

15. Кравець Л. В. Стилістика української мови : Практикум : [навчальний посібник] / Лариса Вікторівна Кравець; за ред. Л. І. Мацько. - К. : Вища школа, 2004. - 199 с.

16. Леонтьев А. А. Психолингвистические проблемы массовой коммуникации [монография] / Алексей Алексеевич Леонтьев. - М. : Издательство «Наука», 1974. - 147 с.

17. Лингвистический энциклопедический словарь [глав. ред. В. Н. Ярцева]. - М. : Советская энциклопедия, 1990. - 685 с.

18. Мацько Л. І. Стилістика української мови : [підручник] / Л. І. Мацько, О. М. Сидоренко, О. М. Мацько; за ред. Л. І. Мацько. - К. : Вища школа, 2003. - 462 с.

19. Мова сучасної масово-політичної інформації / І. К. Білодід, М. М. Пилинський, К. В. Ленець, Г. М. Колесник, Н. М. Сологуб, А. Ф. Марахова, Д. Х. Баранник, I. О. Соколова. - К. : Наукова думка. - 1979. - 252 с.

20. Назайкин А. Н. Эффективный рекламный текст в СМИ : [монография] / Александр Николаевич Назайкин. - М. : Издательство Московского университета : Факультет журналистики МГУ имени М. В. Ломоносова, 2011. - 480 с. 
21. Обритько Б. А. Реклама і рекламна діяльність: [курс лекцій] / Борис Абрамович Обритько. - К. : МАУП, 2002. - 240 с.

22. Пономарів О. Д. Стилістика сучасної української мови : [підручник] / Олександр Данилович Пономарів. - [3-тє вид., перероб. і доповн.] - Тернопіль: Навчальна книга - Богдан, 2000. - 248 с.

23. Почепцов Г. Г. Теорія комунікації / Георгій Почепцов. - К. : Спілка рекламістів України, 1996. - 198 с.

24. Примак Т. О. Маркетингові комунікації: [навчальний посібник] / Т. О. Примак. - К. : Ельга, Ніка-Центр, 2003. - 280 с.

25. Райгородский Д. Я. Реклама: внушение и манипуляция. Медиаориентированный подход. [учебное пособие для факультетов психологии, социологии, экономики и журналистики] / Д. Я. Райгородский. - Самара : Издательский Дом «БАХРАХ-М», 2007. - 752 с.

26. Різун В. В. Теорія масової комунікації : [підручник для студентів галузі 0303 «журналістика та інформація»] / Володимир Володимирович Різун. - К. : Видавничий цент «Просвіта», 2008. - $260 \mathrm{c.}$

27. Розенталь Д. Э. Язык рекламных текстов : [учебное пособие для факультетов журналистики вузов / Розенталь Дитмар Эльяшевич, Кохтев Николай Николаевич. М. : Высшая школа, 1981. - 125 с.

28. Селіванова О. Сучасна лінгвістика : термінологічна енциклопедія / Олена Селіванова. - Полтава : Довкілля - К, 2006. - 716 с.

29. Семенюк О. Основи теорії мовної комунікації : [навчальний посібник для студентів вищих навчальних закладів] / О. А. Семенюк, В. Ю. Паращук. - К. : Ін Юре, 2009. - 276 c.

30. Словник іншомовних слів / [за ред. О. С. Мельничука]. - К. : УРЕ, 1974. - 775 с.

31. Словник української мови [Текст] : в 11 т. / [редкол. : І. К. Білодід та ін.]; Акад. наук Укр. РСР, Ін-т мовознавства ім. О. О. Потебні. - К. : Наукова думка, 1970-1980. $-\mathrm{T}$. I-XI.

32. Стилистический энциклопедический словарь русского языка [глав. ред. М. Н. Кожина; члены редкол.: Е. А. Баженова, М. П. Котюрова, А. П. Сковородников. - М. : Флинта : Наука, 2006. - 696 с.

33. Сэндидж Ч. Реклама: теория и практика / Ротцолл К., Сэндидж Ч., Фрайбургер В. - М. : Прогресс, 1989. - 630 с.

34. Тюрина С. Ю. О понятиях рекламный дискурс и рекламный текст / С. Ю. Тюрина // Вестник ИГЭУ. - Вып. № 1. - 2009. - С. 1-3.

35. Цвиллинг М. Я. Общие и частные проблемы функциональных стилей / Л. И. Зильберман, Е. С. Троянская, М. Я. Цвиллинг, В. Н. Шокуров; за ред. М. Я. Цвиллинг. - М. : Издательство «Наука», 1986. - 216 с. 